Original Research Report

\title{
Correlation between Complication in Pregnancy and Postpartum Depression: Literature Review
}

\author{
Desy Meldawati ${ }^{1}$, Winda Ayu Fazraningtyas ${ }^{2}$, Setia Budi ${ }^{2}$ \\ ${ }^{1}$ Department of Nursing, Faculty of Health, Sari Mulia University. Banjarmasin, \\ Indonesia. \\ ${ }^{2}$ Department of Science in Pharmacy, Faculty of Health, Sari Mulia University. \\ Banjarmasin, Indonesia.
}

Article History
Received:
18.12 .2020
Revised:
03.01 .2021
Accepted:
10.02 .2021
*Corresponding Author:
Desy Meldawati
Email:
desymeldawati@icloud.com

This is an open access article, licensed under: $C C-B Y-S A$
Abstract: Postpartum depression is a depression syndrome that occurs in mothers after childbirth and can be prevented and cured. According to Fazraningtyas, in South Kalimantan, to be precise in the city of Banjarmasin, namely Ulin General Hospital of Banjarmasin and Dr. H.M. Ansari Saleh General Hospital of Banjarmasin showed $56.8 \%$ mild postpartum depression, $26.1 \%$ moderate postpartum depression, $17.0 \%$ severe postpartum depression. The impact of mothers experiencing postpartum depression is that mothers have difficulty interacting and can endanger their children. Postpartum depression is caused by several factors, the factors that contributed are complications in pregnancy. This study used a literature review approach. The articles obtained from Google Scholar, Biomed Central, and Pubmed. The criterias applied be restricted. As many as 10 journals are found. Based on the previous study, complications in pregnancy are the cause of postpartum depression. Complications that are often experienced by pregnant women are maternal anemia that can appear during the pregnancy process until the birth process occurs and $30-70 \%$ of pregnant women with maternal anemia have a risk of postpartum depression. Second, gestational diabetes is one of the complications of pregnancy that occurs in women who are pregnant. Pregnant women can increase hormones including the progesterone hormone, human placental lactogen estrogen, and cortisol. The last, a history of depression is a cause of postpartum depression because if pregnant women have a history of depression before pregnancy, they will have a higher risk of experiencing postpartum depression.

Keyword: Complication in Pregnancy, Cortisol, Human Placental Lactogen Estrogen, Postpartum Depression, Progesterone Hormone. 


\section{Introduction}

Postpartum what is called the puerperium is a life struggle of a mother, especially mothers who have had children for the first time and have just become a mother [1]. Postpartum depression that is helped by a new mother can interfere with her usual daily activities. Postpartum depression can also have an effect on comfort, happiness, a mother's love for her new baby, because of mood disorders and easy stress [2].

A pregnant mother can experience physiological changes during her pregnancy, both physical changes and psychological changes [3]. Psychological changes that occur in pregnant women during pregnancy are usually difficult for pregnant women to accept. Psychological changes that often occur during pregnancy, such as changes in attitudes, feelings, and a mother also takes time to adjust [4].

Depression that helps women in the world reach $10 \%$ in pregnant women and $13 \%$ in postpartum mothers. There are more women who experience depression in developing countries than in developed countries. In developing countries, $15.6 \%$ of women experience depression during pregnancy, while $19.8 \%$ of women experience depression during the postpartum period [5]. In Indonesia, there are no data as a whole on women who experience postpartum depression. The results of the study found that mothers who experienced postpartum depression in Denpasar were $20.5 \%$ [6].

The results of research by Fazraningtyas, in South Kalimantan, precisely in the City of Banjarmasin in two hospitals, namely the Ulin Banjarmasin Regional General Hospital and Dr. H.M. Ansari Saleh Banjarmasin showed that $56.8 \%$ of mothers had mild postpartum depression, $26.1 \%$ of mothers had moderate postpartum depression, and $17.0 \%$ of mothers had severe postpartum depression [7].

According to [8] Postpartum depression is a depression syndrome which is not a symptom of psychosis that occurs in mothers after childbirth and can be prevented and cured. Based on the results of a preliminary study conducted at the Ulin Banjarmasin Hospital, data on the number of post-partum mothers for 8 months from January to August 2019 were 834 postpartum mothers who were treated at the Ulin Banjarmasin Regional General Hospital. The average number of post-partum mothers who are hospitalized every month is 104.

Postpartum depression is caused by various factors, one of the complications of pregnancy is very dangerous for the health of the mother and baby and is a contributing factor to postpartum depression [9]. According to [10] The psychological condition of the mother after giving birth can change. In Indonesia there are several studies on postpartum depression. However, existing research only focuses on risk factors based on occupational demographic data, age, type of delivery, family support and others. Therefore, researchers are interested in conducting research on the relationship between pregnancy and the incidence of postpartum depression.

\section{Literature Review}

Postpartum depression is a psychological disorder that is often served by some postpartum mothers. This disorder is a feeling of sadness, crying, anxiety, fear, feeling lonely, suspicious, decreased appetite, sleep disturbances, difficulty concentrating, feelings of worthlessness, loss of hope, interest in the baby's interest, and feelings of being unable to become a mother, even in some cases, hallucinations so that the mother tries to divorce the baby, yourself or others [11]. Based on the results of the literature review, the factors that contribute to the incidence of postpartum depression are generally divided into 3 factors.

The first factor is biological factors such as physiological changes during pregnancy, childbirth and postpartum, nutritional deficiencies, metabolic disorders, anemia, decreased estrogen and progesterone hormones after childbirth, decreased cytokines, changes in fatty acids and oxytocin as well as obstetric complications suffered by the mother. Second, psychosocial factors such as failure in marriage, lack of support from partners and other loved ones, poor relationships with partners and inlaws, domestic violence, a history of affective disorders such as a history of previous pregnancy depression, a history of depression in the family, mood disorders during menstruation.

Third, demographic factors such as maternal age, education, occupation, parity, culture or prevailing norms. Apart from that, the causes of postpartum depression with pregnancy in this literature review most often appear due to maternal anemia, gestational diabetes (hyperglycemia) and depression before pregnancy. 
(the body cannot use insulin effectively) and can increase the increase in sugar levels in the blood [13].

Gestational diabetes usually occurs in people who are overweight, especially in the abdominal area, have a sedentary lifestyle, have hypertension, and have a history of heart disease, stroke, or depression. Furthermore, gestational diabetes (hyperglycemia) during pregnancy has a greater chance for the incidence of postpartum depression [14].

History of depression has an effect on the risk of postpartum depression related to age, mode of delivery, and the presence of diabetes. The history of depression before pregnancy will cause postpartum discomfort, sleep disturbances, changes in appetite, decreased energy, and difficulty concentrating. Women with a history of depression before pregnancy are more likely to experience postpartum depression [15].

Anxiety that makes pregnant women can be a stressor in the prenatal period so that it will cause an increase in cortisol which will have an impact on preterm birth. Therefore, interventions are needed that can protect pregnant women from stress in the form of social support from partners, loved ones and health workers [16].

Nurses as care providers for perinatal mothers are expected to be able to provide holistic nursing care, so that various psychological problems during the perinatal period can be prevented. These efforts have been implemented in integrated antenatal services, through pregnancy examinations, conducting classes for pregnant women by providing various health education materials and implementing pregnancy exercises. In addition to these efforts, various nursing model developments were also carried out in the prevention of depression prevention during the perinatal period [15].

\section{Summary and Conclusion}

This study aims to correlate the relationship between pregnancy and the incidence of postpartum depression. This study used a literature review approach. The articles obtained from Google Scholar, Biomed Central, and Pubmed. The criterias applied be restricted. As many as 10 journals are found. Complication in pregnancy is one of the risk factors of postpartum depression, i.e., maternal anemia, gestational diabetes, dan previous depression. Future researchers are expected to be able to conduct research based on primary data.

\section{References}

[1] R. Y. Astutik, Buku Ajar Asuhan Kebidanan Masa Nifas dan Menyusui. Jakarta: Trans Info Media, 2015.

[2] American Psychological Association (APA), "What is Postpartum Depression \& Anxiety," 2017. [Online]. Available: www.apa.org/pi/women/resources/report s/postpartum_depression .aspx. [Accessed: July 2020].

[3] J. H. Park, W. Karmaus and H. Zhang, "Prevalance of and Risk Factors for Depressive Symptoms in Korean Women Throught Pregnancy and in Postpartum," Asian Nursing Research, vol. 8, no. 3, pp. 219-225, 2015.

[4] A. Pillitteri, "Maternal and Child Health Nursing: Care of the Childbearing and Childrearing family (Ed. 7). Philippines: Lippincott Williams and Wilkins," 2014.

[5] WHO, "Gender and Women's Mental Health," 2017. [Online]. Available: http://www.who.int/ mentalhealth/prevention/genderwomen/en/. [Accessed February 2020].

[6] I.K.P.A Dira, and A.S.S. Wahyuni, "Prevalensi Dan Faktor Risiko Depresi Postpartum Di Kota Denpasar Menggunakan Edinburgh Postnatal Depression Scale," E-Jurnal Medika. vol. 5, no. 7, pp. 1-5, 2016.

[7] W. A. Fazraningtyas, "Hubungan Faktor Sociodemographic Dengan Depresi Postpartum Di Rumah Sakit Daerah Banjarmasin," Dinamika Kesehatan Jurnal Kebidanan dan Keperawatan, vol. 10, no. 1, pp. 461-469, 2019.

[8] M. Patel, R. K. Bailey, S. Jabeen and S. Ali, "Postpartum Depression: A review," J Health Care Poor Underserverd, vol. 23, no. 2, pp. 534-542, 2012.

[9] A. Sari, I. K. Ulfa and R. Daulay, Asuhan Kebidanan Pada Kehamilan. Bogor: Penerbit IN MEDIA, 2015.

[10] R. Hildayani, Manajemen Kesehatan Mental Sebelum dan saat Kehamilan. Preconception and pregnancy nutrition for health preagnancy, 2016. 
[11] W. A. Fazraningtyas, A. Sari and D. Rahmayani, "Obstetrical Factors in Postpartum Depression: A Correlational Study at General Hospitals of Banjarmasin" Journal of Clinical Inventions and Medical Sciences, vol. 2, no. 1, pp. 8-14, 2020.

[12] F. Kusumawardani, Rodiani and A. Y. Prabowo, "Hubungan Anemia Maternal dengan Depresi Postpartum," Majority, vol. 7, no. 2, pp. 217-221, 2018.

[13] F. Rahmawati, J. Natosba and Jaji, "Skrining Diabetes Mellitus Gestasional Dan Faktor Risiko Yang Mempengaruhinya," Jurnal Keperawatan Sriwijaya vol. 3, no. 2, pp. 33-43, 2016.

[14] Cabrera, "Postpartum problems in primary care: focus on postpartum depression and diabetes," Journal of the American Association of Nurse Practitioners, vol. 9, no. 2, pp. 12-21, 2019.

[15] M. E. Silverman, A. Reichenberg, D. A. Savitz, S. Cnattingius, P. Lichtenstein, C. M. Hultman, H. Larsson and S. Sandin, "The Risk Factors for Postpartum Depression: A Population Based Study," Depress Anxiety, vol. 8, no. 4, pp. 1-10, 2017.

[16] J. L. Barkin, K. L. Wisner, J. T. Bromberger, S. R. Beach and S. R. Wisniewski, "Factors Associated with Postpartum Maternal Functioning in Women with Positive Screens for Depression," Journal of Womens Health, vol. 7, no. 3, pp. 22-29, 2016.

[17] S. Tebeka, Y. L. Strat, and C. Dubertret, "Developmental trajectories of pregnant and postpartum depression in an epidemiologic survey" Journal of Affective Disorders. vol. 203, pp. 62-68, 2016.

[18] Iskandar and R. Sofia, "Hubungan Stresor Psikososial Pada Kehamilan Dengan Komplikasi Persalinan Di Wilayah Kerja Puskesmas Lapang Aceh Utara," Jurnal Averrous, vol. 5, no. 1, pp. 1-15, 2019.

[19] Murwati and Suroso, "Penerapan Cognitif Behavior Therapi (CBT) pada Ibu Nifas Sebagai Upaya Pencegahan Depresi Post Partum di Kabupaten Klaten," Jurnal Kebidanan dan Kesehatan Tradisional, vol. 2, no. 2, pp. 60-115, 2017.

[20] Immawanti, "Penggunaan Mommoodbooster (MMB) Sebagai Intervensi Pada Ibu Dengan Depresi Postpartum,” Jurnal Kesehatan Marendeng, pp. 10-16, 2017. 